\title{
Kautilya and Machiavelli on Justice, Prosperity and National Security
}

\author{
Balbir S. Sihag \\ University of Massachusetts Lowell, Lowell, USA \\ Email: balbir_sihag@uml.edu
}

How to cite this paper: Sihag, B.S. (2017) Kautilya and Machiavelli on Justice, Prosperity and National Security. Theoretical Economics Letters, 7, 381-397. https://doi.org/10.4236/tel.2017.73029

Received: February 16, 2017

Accepted: March 28, 2017

Published: March 31, 2017

Copyright $\odot 2017$ by author and Scientific Research Publishing Inc. This work is licensed under the Creative Commons Attribution International License (CC BY 4.0).

http://creativecommons.org/licenses/by/4.0/

\section{(c) (i) Open Access}

\begin{abstract}
As soon as Kautilya's Arthashastra was translated into English in 1915, its comparison with Machiavelli's Prince, particularly by the western Indologists, started in earnest. Their main goal has been to show that Machiavelli's Prince was pale in comparison to the ruthless realism in Kautilya's Arthashastra. Several user-friendly tables are constructed from the texts in The Arthashastra and Prince to i) strongly refute and correct such distortions and misrepresentations of Kautilya's ideas, and ii) show Kautilya had much deeper understanding of the issues than Machiavelli. Interestingly, a closer look reveals that Machiavelli, although far less than Kautilya, but had deeper insights into economic issues than Adam Smith. It is also indicated that Kautilya, just with one sentence, captured the essence of liberty as empowerment of the weak against the powerful, Mill could not do that with his whole book on Liberty.
\end{abstract}

\section{Keywords}

Child Labor, Kautilya's Arthashastra, Kissinger's World Order, Machiavelli's Prince, Mill's Liberty, Sexual Harassment, Smith's Wealth of Nations

\section{Introduction}

As soon as [1] Machiavelli's Prince was indexed in 1559, his name and the word evil, although incorrectly, became interchangeable. Machiavelli advocated a cruel and callous approach as to how a new king should retain his kingdom. First translation of the Arthashastra in English by Shamasastry was published in 1915 and almost immediately, its comparison with Machiavelli's Prince started in earnest. Numerous political science scholars, apparently without fully understanding or reading [2] Kautilya's Arthashastra, have been inappropriately comparing Kautilya to Machiavelli. [3] Kangle (1965/2000, Ch. 12) presents the views of several authors on such comparison. Most of the western scholars set 
out to show that Kautilya was as much if not more callous than Machiavelli in his approach. Even seasoned [4] Henry Kissinger (2014) has taken the same distorted and beaten track. The primary source of their confusion, misrepresentation or distortion seems to be that all these scholars have focused only on one part, how to protect the nation against traitors and aggressors (national security), of the Arthashastra and ignored Kautilya's monumental contributions to economic principles and policies and administration of justice. However, according to Kautilya, traitors, just like filth, must be flushed out of the system and aggressors must be destroyed so that ordinary people could enjoy both peace and prosperity (Yogakshema).

Machiavelli, just like Kautilya, was an honest and hard-working individual. So the intended comparison is not about them as such but related to the approach, purpose, vision, scope and depth of analysis of their works. Kautilya had a long term horizon, was forward-looking and has been acknowledged as a king-maker. He had a vision of a prosperous, secure and secular nation, developed a conceptual framework and formulated appropriate policies to realize his vision. Everything relevant to the wellbeing of the people is discussed in depth. His Arthashastra is comprehensive, coherent, consistent and original. Machiavelli, on the other hand was seeking a job. He sent his letter and manuscript of his Prince in support of his application for the job. He had a very short term horizon, was often backward-looking and had no vision. Consequently he covered very few, although similar, topics, did not analyze any topic in depth and was often inconsistent. Also, there is nothing original in the Prince. Machiavelli just collected the insights of others. For fuller understanding of these works some background on differences between Kautilya's Arthashastra and Machiavelli's Prince related to: a) the vision and scope of their works; b) their approaches; c) king's character, d) human nature and e) role of advisers are presented in Sections 2, 3, 4, 5 and 6 respectively.

Kautilya's Arthashastra is a manual on how to promote Yogakshema-peaceful enjoyment of prosperity-for all the people. Sihag [5] presents Kautilya's policies on enriching the people ${ }^{1}$. On the other hand, Machiavelli mentions that the king should take care of his public but there is absolutely no discussion about any policy or program to enrich them. This discussion is presented in Section VII. Apparently Machiavelli understood the importance of good laws, but unlike Kautilya, did not discuss how to formulate and implement such laws. Section VIII contains their differences related to administration of justice. Sihag [7] presents Kautilya's comprehensive, proactive and prudent approach to national security and the link between prosperity and national security. Machiavelli did not offer any comprehensive approach to national security and also did not understand the link between prosperity and national security. Machiavelli makes some ad hoc remarks related to making alliances, role of information and public support and these are collected in Section 4.

${ }^{1}$ For example, Sihag [7] has shown that Kautilya's Arthashastra has more depth and breadth than that of [9] Adam Smith's The Wealth of Nations. 


\section{Comparing Kautilya's Vision to Machiavelli's}

There are sharp differences related to the vision and scope of their works. Kautilya was focused on nation-building. He had a grand vision of building an empire encompassing the whole of Indian-subcontinent, with diversified and productive economy in which people were honest and hard-working and could enjoy prosperity and security. Machiavelli was desperately looking for a job and could not afford the luxury of entertaining a vision and therefore did not see the need to develop any conceptual framework or program to bring prosperity or security to the people. The following Table 1 compares the vision and scope of their works.

Dharma and Artha: Kautilya gave the highest priority to the preservation and promotion of dharma, that is, to the practice of secular virtues, such as non-violence, compassion, tolerance, freedom from malice, truthfulness and honesty. He, just like the Vedic seers, assigned a foundational role to dharma. He believed if there were no dharma there would be no society. According to Kautilya, role of dharma was not only foundational but also instrumental to the promotion of artha (prosperity), that is, dharma not only paved the path to bliss but also to prosperity. He (p. 142) explained, "Government by Rule of Law, which alone can guarantee security of life and welfare of the people, is, in turn, dependent on the self-discipline of the king (1.5)." That is, economic growth depended on rule of law and that in turn depended on ethical conduct of the king. He (pp. 107-108) emphasized, "For the world, when maintained in accordance with the Vedas, will ever prosper and not perish. Therefore, the king shall

Table 1. Vision and Scope of the Arthashastra and the Prince.

Kautilya
Kautilya's Vision: Kautilya stated his vision as: "The kingdom shall be
protected by fortifying the capital and the towns at the frontiers. The
land should not only be capable of sustaining the [native] population
but also outsiders [when they come into the kingdom] in times of
calamities. It should be easy to defend from [attacks by] enemies and
strong enough to control neighboring kingdoms. It should have
productive land (free from swamps, rocky ground, saline land, uneven
terrain and deserts as well as wild and [unruly] groups of people). It
should be beautiful, being endowed with arable land, mines, timber
forests, elephant forests, and good pastures rich in cattle. It should not
depend [only on] rain for water. It should have good roads and
waterways. It should have a productive economy, with a wide variety of
commodities and the capacity to sustain a high level of taxation as well
as a [large] army. The people shall be predominantly agriculturists
[artisans and craftsman], devoted to work, honest, loyal and with
intelligent masters and servants."

Scope: Kautilya explained the scope as: "By following [the principles set out in] this treatise one can not only create and preserve dharma [spiritual good], artha [material well-being] and kama [aesthetic pleasures] but also destroy [their opposites, i.e.,] unrighteousness, material loss and hatred. It is a guide not only for the acquisition of this world but also the next."
Machiavelli on Irrelevance of a Vision: He (513, p 48) describes, "But my hope is to write a book that will be useful, at least to those who read it intelligently, and so I thought it sensible to go straight to a discussion of how things are in real life and not waste time with a discussion of an imaginary world. For many authors have constructed imaginary republics and principalities that have never existed in practice and never could; for the gap between how people actually behave and how they ought to behave is so great that anyone who ignores everyday reality in order to live up to an ideal will soon discover he has been taught how to destroy himself, not how to preserve himself."

Scope: Machiavelli (p 3) wrote in his letter to Francesco Vettori, "I discuss what a principality is, how many types of principality there are, how one acquires them, how one holds onto them, why one loses them." 
never allow the people to swerve from their dharma (1.3.17)." He (p. 177 added, "Ever victorious and never conquered shall be that Kshatriya, who is nurtured by Brahmins, made prosperous by the counsels of able ministers and has, as his weapons, the precepts of the shastras (1.9.11)." He (p. 141) warned, "A king who flouts the teachings of the Dharamshastras and The Arthashastra, ruins the kingdom by his own injustice (8.2).”

Henry Kissinger (2014) remarks, "Like Machiavelli's, his is an analysis of the world as he found it; it offers a practical, not a normative, guide to action. And its moral basis is identical with that of Richelieu, who lived nearly two thousand years later: the state is a fragile organization, and the statesman does not have the moral right to risk its survival on ethical restraint." Kissinger is correct in claiming that Machiavelli accepted the world as he found it but is dead wrong about Kautilya. As presented above, Kautilya had a vision of shared prosperity, developed a conceptual framework and offered normative yet actionable guidelines to realize it. [6] Drekmeier (1962, p. 76) puts it very aptly as: "Now the king must concern himself directly with the common good, an idea anticipated in the Arthashastra." He (p. 201) asserts, "There can never be a thoroughgoing divorce of politics and ethics for Kautilya; he never denies that the ultimate purpose of the state is a moral purpose, the maintenance of dharma." He (p. 202) adds, "For all his commitment to a philosophy of opportunism and force, Kautilya would not have limited might to mere physical mastery. Such may be the primary obligation of warrior and even king, but the ultimate power is spiritual." He (2003) adds, "Self-mastery and world-mastery are interdependent."

Richelieu certainly pursued national interest and his own interest by following the maxim: end justifies the means. Kautilya believed in the concept of moral duty. But attributing the concept of 'moral duty' to Richelieu is incorrect. Richelieu was a religious person but not ethical. He was a self-serving and power-hungry monster in a cardinal's red robe.

Machiavelli (chap. 7, p. 27) listed his suggestions as to what a new ruler needed to do to stay in power. These were: "So anyone who decides that the policy to follow when one has newly acquired power is to destroy one's enemies, to secure some allies, to win wars, whether by force or by fraud, to make oneself both loved and feared by one's subjects, to make one's soldiers loyal and respectful, to wipe out those who can or would want to hurt one, to innovate, replacing old institutions with new practices, to be both harsh and generous, magnanimous and open-handed, to disband disloyal troops and form new armies, to build alliances with other powers, so kings and princes either have to win your favor or else think twice before going against your wishes-anyone who thinks in these terms cannot hope to find, in the recent past, a better model to imitate than Cesare Borgia." But he does not offer any policy or program to achieve any of his suggestions. Use of "force or fraud" implies no role for ethics. Cicero had remarked that fear was incompatible with love so how one accomplishes to be "loved and feared".

We may summarize that Dharma and artha form the core of Arthashastra and 
Roger Boesche, Henry Kissinger and many others have an inadequate understanding of Indian culture and of economics and therefore fail to appreciate and acknowledge Kautilya's unique contribution and keep comparing Kautilya to some mediocre writers. Machiavelli provided inadequate analysis and the Prince has a very limited scope.

\section{Comparing Kautilya's Approach to Machiavelli's}

Kautilya and Chandragupta Maurya inherited an economy in shambles. At that time there was no such thing as live and let live and threat of an aggression by unscrupulous, murderer and neurotic rulers like Alexander was real. Kautilya wrote the Arthashastra, a manual on promoting Yogakshema-peaceful enjoyment of prosperity-for all the people. That is, i) how to engineer prosperity, ii) how to ensure security and iii) of all the people. Kautilya realized that one uniform set of values or one single approach would not help in realizing his vision. Keeping that in view, Kautilya suggested a people-centric, ethical and proactive approach towards king's own subjects but proactive and a mix of ethical approach and pragmatic approach towards other rulers. In other words, idealism for the domestic affairs and a mix of idealism and realism for the international affairs.

David Wootton ( $\mathrm{p}$ xxii) believes, "Machiavelli may appear to teach the immoral pursuit of power by any means. In fact, he clearly teaches two sets of moral values: one deals with relations between states, where only success counts; the other much more complex, concerns one's dealings with one's fellow citizens, where the means must be justified by the purposes they serve." Actually, Machiavelli's approach towards own subjects and towards others was practically the same: king-centric, proactive and pragmatic. Machiavelli does not assign any role to moral values whether the king was dealing with his own subjects or others, that is, there was only one set of immoral values and not two sets of moral values. The following Table 2 is intended to capture these differences.

According to Kautilya (p 182), "Every man has an obligation to maintain his wife, children, parents, minor brothers and dependent (unmarried or widowed) sisters. No man shall renounce the life of a householder in order to become an ascetic without providing for the maintenance of his wife and children (2.1)." The head of the household is primarily responsible for the family and there is a punishment of 12 panas (p. 194) for the failure $(2.1)^{2}$. Kautilya also suggested remedial measures if a famine or flood occurred despite efforts to prevent them.

We may conclude that Kautilya emphasized moral duty of the king to his sub-

${ }^{2}$ Boesche [10] remarks, "Paternalistic in an almost literal sense, Kautilya saw the people of the kingdom not as active citizens but as passive subjects cared for by the king and the state. Arguably the entire notion of a welfare state, in which the state was responsible for those in need either by providing jobs or by supporting those who could not survive without assistance, was first described in the history of political ideas by Kautilya."

Kautilya recommends that the government not only should help the old, sick, children and the helpless but also should provide insurance against natural disasters to everyone. Thus the usual distinction between a residual and a universal welfare state may not be a very useful one in describing Kautilyan state (See [11] Barr (1992) for such a distinction). 
Table 2. Comparison of the Approaches.

Kautilya's Approach

People-centric. (a) "In the happiness of his subjects lies his happiness; in their welfare his welfare. He shall not consider as good only that which pleases him but treat as beneficial to him whatever pleases his subjects (1.19)."

(b) He (p 128) wrote, "Whenever danger threatens, the king shall protect all those afflicted like a father [protects his children] (4.3)."'

(c) He (p 180) added, "He shall, however, treat leniently, like a father [would treat his son], those whose exemptions have ceased to be effective (2.1)."

(d) Kautilya (p 182) suggested, "King shall maintain, at state expense, children, the old, the destitute, those suffering from adversity, childless women and the children of the destitute women (2.1)."

(e) Kautilya (p 128) believed, "It is the duty of the king to protect the people from all calamities (4.3)."

Ethical: He (p 180) wrote, "For, when adharma overwhelms dharma, the King himself will be destroyed (3.16.42)." He (p 639) stated, "Wealth is like a tree; its roots are dharma and the fruit is pleasure. Achieving that kind of wealth which further promotes dharma, produces more wealth and gives more pleasure is the achievement of all gains (sarvarthasiddhi) (9.7.81)."

Proactive: He (p 116) wrote, "In the interests of the prosperity of the country, a king should be diligent in foreseeing the possibility of calamities, try to avert them before they arise, overcome those which happen, remove all obstructions to economic activity and prevent loss of revenue to the state (8.4)."

Pragmatic. (p 541): “An enemy's destruction shall be brought about even at the cost of great losses in men, material and wealth (7.13)."
Machiavelli's Approach

King-centric. Page 31: "Do all the harm you must at one and the same time, that way the full extent of it will not be noticed, and it will give least offense, one should do good, on the other hand, little by little, so people can fully appreciate it."

Page 49: "Above all, do not be upset if you are supposed to have those vices a ruler needs if he is going to stay securely in power, for, if you think about it, you will realize there are some ways of behaving that are supposed to be virtuous [che parra vjtu], but would lead to your downfall, and others that are supposed to be wicked, but still lead to your welfare and peace of mind."

Unethical: page 55: "A ruler, and particularly a ruler who is new to power, cannot conform to all those rules that men who are thought good are expected to respect, for he is often obliged, in order to hold on to power, to break his word, to be uncharitable, inhumane, and irreligious. So he must be mentally prepared to act as circumstances and changes in fortune require. As I said, he should do what is right if he can; but he must be prepared to do wrong if necessary."

Proactive: Page 11: "It is necessary not only to pay attention to immediate crises, but to foresee those that will come, and to make every effort to prevent them."

Page 35: "They all have appropriate moats and ramparts, and more than enough artillery. They always keep in the public stores enough food and drink, and firewood, to be able to hold out for a year."

Pragmatic. Page 55: "So if a ruler wins wars and holds on to power, the means he has employed will always be judged honorable, and everyone will praise them."

jects like a father to his children. He envisioned a well governed, well organized, prosperous and progressive state but not a welfare or centrally planned one. His approach was people-centric. On the other hand, Machiavelli focused exclusively on the self-interest of the king.

\section{Their Relative Views on King's Character}

Machiavelli's king was more like a stationary bandit whereas Kautilya's king was a rajarishi whose goal was to uplift people out of poverty. According to Kautilya, king was a faithful servant of his subjects. This concept is alien to the west. Kautilya believed that only a rajarishi could follow a people-centric and ethical approach. Drekmeier (1962, p. 25) notes, "In conclusion, we may say that early Indian kingship was broadly contractual, conceived of as a trust, subject to popular 
approval, and, most important, subject to higher law and certain other restraints, normative and practical. It was basically a secular institution.” (Table 3 ).

Thus, according to Kautilya, a king must have a good knowledge of philosophy but should not be an idle philosopher, or a dictator rather should be an impartial, benevolent, far-sighted, foresighted, disciplined and energetic doer. On the other hand, Machiavelli suggested that a king should pretend to be ethical but need not behave ethically, that is ready to cheat. Then in his other writing, he suggested that a king should be a role model.

\section{Their Underlying Assumptions Regarding Human Nature}

Kautilya believed that there were moral, amoral and immoral types of people whereas Machiavelli believed that all people were amoral or immoral (Table 4).

Kautilya believed in ethical anchoring of young children. He (pp. 155-156) wrote, "There can be no greater crime or sin', says Kautilya, 'than making wicked impressions on an innocent mind. Just as a clean object is stained with whatever is smeared on it, so a prince, with a fresh mind, understands as the

Table 3. Differences Regarding the Character of the King.

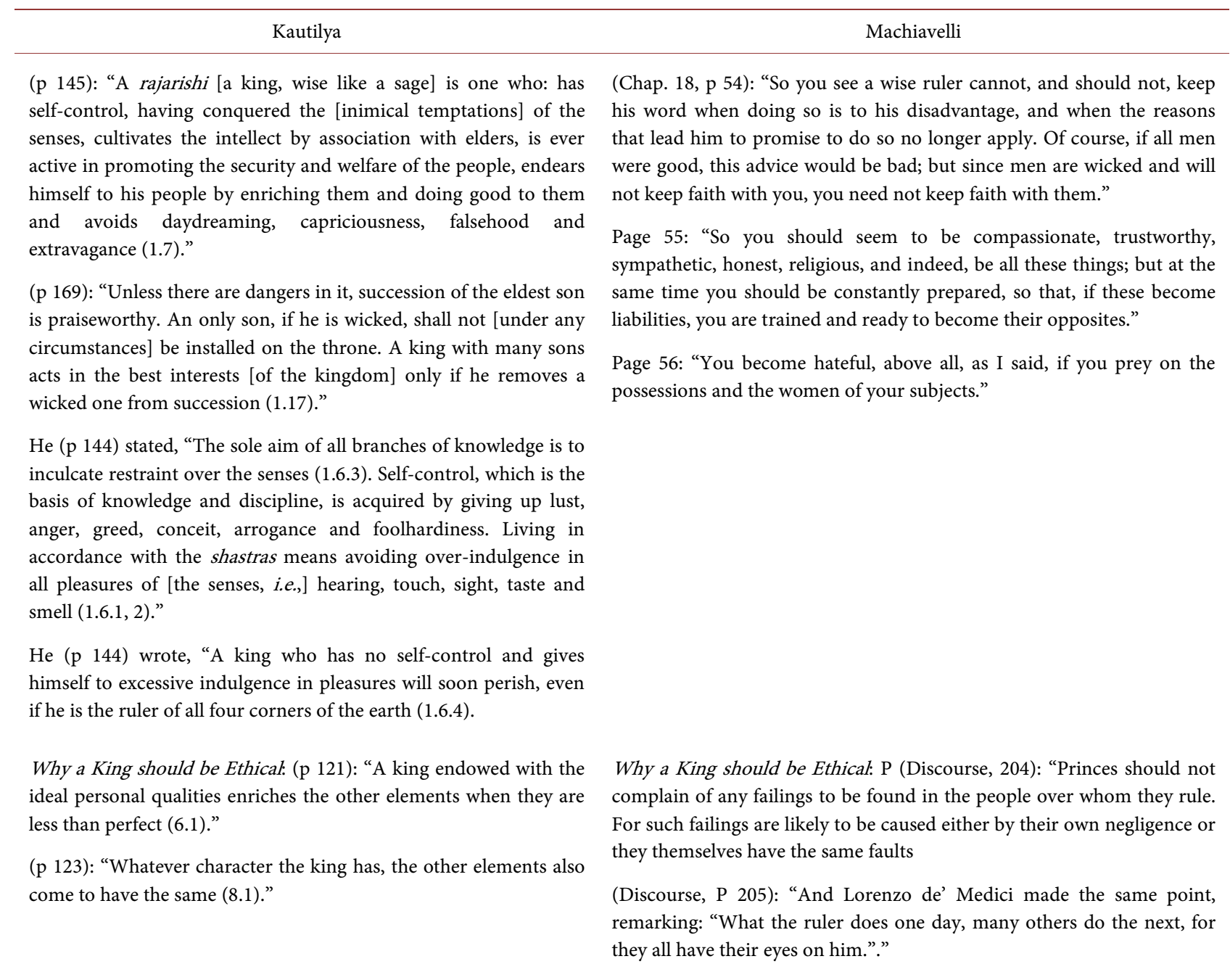


Table 4. Differences Related to Human Nature.

\begin{tabular}{|c|c|}
\hline Kautilya & Machiavelli \\
\hline $\begin{array}{l}\text { Page 124: "For the fort, the treasury and the army all depend on the people; } \\
\text { so do the reservoirs. All economic activity has its source in the countryside. } \\
\text { Bravery, stability and cleverness are also found among the country people } \\
(8.1 .28-31) . "\end{array}$ & $\begin{array}{l}\text { Page 52: "For of men one can, in general, say this: They are } \\
\text { ungrateful, fickle, deceptive and deceiving, avoiders of danger, } \\
\text { eager to gain." He adds, "Men are less nervous of offending } \\
\text { someone who makes himself lovable, than someone who makes }\end{array}$ \\
\hline $\begin{array}{l}\text { P 169: "Sons are of three kinds: a wise son is one who understands dharma } \\
\text { and artha when taught and also practices these. A lazy son is one who } \\
\text { understands what he is taught but does not practice them. A wicked son is } \\
\text { he who hates dharma and artha and [therefore] is full of evil." }\end{array}$ & $\begin{array}{l}\text { himself frightening. For love attaches men by ties of obligation, } \\
\text { which, since men are wicked, they break whenever their } \\
\text { interests are at stake. But fear restrains men because they are } \\
\text { afraid of punishment, and this fear never leaves them. Still, a } \\
\text { ruler should make himself feared in such a way that, if he does }\end{array}$ \\
\hline $\begin{array}{l}\text { Page 664: "There are three types of aggressors: (i) The righteous aggressor is } \\
\text { satisfied with submission. (ii) The greedy aggressor is satisfied with seizing } \\
\text { land and goods. (iii) The monstrous aggressor is satisfied only when he takes } \\
\text { the land, goods, wives, sons and [even the] life of the defeated." }\end{array}$ & $\begin{array}{l}\text { not inspire love, at least he does not provoke hatred. For it is } \\
\text { perfectly possible to be feared and not hated. You will only be } \\
\text { hated if you seize the property or the women of your subjects } \\
\text { and citizens." }\end{array}$ \\
\hline
\end{tabular}

truth whatever is taught to him. Therefore, a prince should be taught what is dharma and artha, not what is unrighteous and materially harmful (1.17)."

In conclusion we may say that Kautilya understood the link between character-building and nation-building. Clearly, he wanted to create a more harmonious and caring world and did not accept the existing one as claimed by Henry Kissinger.

\section{Role of Advisers}

There are sharp differences regarding the role of advisers. According to Kautilya, due to bounded rationality a king could not solve complex problems alone by himself. So Kautilya advised appointment of advisers and pooling of their information, knowledge and wisdom with that of the king to arrive at the best possible decision. According to Kautilya, as the number of advisers increased the king would get better advice due to the increased pooling of information and knowledge but as the number of advisers increased the probability of keeping it confidential would be lowered. Thus, Kautilya analyzed the trade-off between efficiency and confidentiality and concluded that the optimum of advisers should not be higher than four (see Sihag (2014, Chap. 10) for a detailed presentation) (Table 5).

Machiavelli thought in the absence of an adviser the king would change his mind due to the influence of his near and dear ones and would appear to be inconsistent. It is not a convincing argument for hiring advisers. First of all, if the king were wise, then he would have realized the inadequacy of his capabilities and also anticipated the reactions of his near and dear ones and consulted them before taking a decision. Secondly, the near and dear ones, according to Machiavelli, most likely were protecting their own interests. So the king could ignore their suggestions. Moreover, the king could still change his mind even if he consulted an adviser, that is, Machiavelli could not justify the hiring of an adviser. +++ 
Table 5. Differences over the role of advisers.

Kautilya
Bounded Rationality: He (p 177) observed, "A king can reign only
with the help of others; one wheel alone does not move a chariot.
Therefore, a king should appoint advisers as councilors and ministers
and listen to their advice (1.7)."
Emphasis on pooling of Knowledge and Information: Kautilya stated,
"Vishalaksha says 'never can a single person arrive at the right
decision. The work of government is dependent on [complete]
knowledge--that which the king personally knows, that which is
reported to him and that which he has to infer. To find out what is
not known, to clarify doubts when there are alternatives, to obtain
more information when only a part is known--all these can be done
only with the help of advisers. Hence a king shall conduct his
deliberations with advisers of mature intelligence. (As the saying
goes :) 'Despise no one, [but] listen to all views; for, wise man pays
heed to all sensible advice, even those of a child' (1.15)."
heed to all sensible advice, even those of a child' (1.15).”

Qualification of an Adviser. He (p, 120) described, “A councilor or minister of the highest rank should be a native of the state, born in a high family and controllable [by the king]. He should have been trained in all the arts and have logical ability to foresee things. He should be intelligent, persevering, dexterous, eloquent, energetic, bold, brave, and able to endure adversities and firm in loyalty. $\mathrm{He}$ should neither be haughty or fickle. He should be amicable and not excite hatred or enmity in others (1.9)."

How many Advisers. He concluded, "[There should be no more than four advisers] because, with more than four, secrecy is rarely maintained. [While, normally, the king should consult three or four advisers,] he may, depending on the nature of the work and the special circumstances of each case, take a decision by himself, consult just one adviser, or even two. The opinions of the advisers shall be sought individually as well as together [as a group]. The reason why each one holds a particular opinion shall also be ascertained (1.15)."

Conflicts of Interest. Kautilya (p, 200) also recommended, "No one who belongs to the side likely to be adversely affected by the project shall be consulted (1.15)."
Page Chap 23, 72: "For the emperor is a secretive man, he keeps things to himself and never asks anyone's advice. But, when his decisions begin to be discovered, which is when they begin to be put into effect, he begins to be criticized by those who are close to him, and, as one might expect, he is persuaded to change his mind. The result is that he undoes each day what he did the day before; that nobody ever knows what he really wants or intends to do; and that one cannot rely upon his decisions.

Chapter 23, Page 72: "A ruler, therefore, always take advice, but only when he wants to, not when others want him to; he should discourage everybody from giving him advice without being asked; but he should be always asking, and, moreover, he should listen patiently to the answers, provided they are truthful."

"For this is a general rule without exceptions: A ruler who is not himself wise cannot be given good advice."

Page 73: "This is how it has to be, for you will find men are always wicked, unless you give them no alternative but to be good. So we may conclude that good advice, no matter who it comes from, really comes from the ruler's own good judgment, and that the ruler's good judgment never comes from good advice."

Qualifications of an Adviser. Chapter 22, page 71: "For there are three types of brains: One understands matters for itself, one follows the explanation of others, and one neither understands nor follows. The first is the best, the second excellent, the third useless."

No discussion on how many advisers a ruler should have

Conflicts of Interest. Page 71: "When you see your adviser give more thought to his own interests than yours, and recognize everything he does is aimed at his own benefit, then you can be sure such a person will never be a good adviser."

However, Machiavelli, just like Kautilya, did understand the principal-agent problem, and the role of efficiency wages. For example, he (p 71) wrote, "On the other hand the ruler, in order to get the best out of his adviser, should consider his adviser's interests, heaping honors on him, enriching him, placing him in his debt, ensuring he receives public recognition, so that he sees that he cannot do better without him, that he has so many honors he desires no more, so much wealth he desires no more, so much status he fears the consequences of political 
upheaval. When a ruler has good advisers and knows how to treat them, then they can rely on each other; when it is otherwise, either ruler or adviser will suffer." Kautilya in addition to paying decent wages, suggested moral incentives also to elicit effort (see Sihag (2014a, Chap.11)) ${ }^{3}$.

Kautilya considered advisers as prized employees since he understood the concept of bounded rationality and the importance of pooling information and knowledge whereas Machiavelli could not justify the need to hire advisers as he was ignorant of the importance of pooling information.

\section{Kautilya and Machiavelli on Economic Growth}

Kautilya just like his predecessors believed that ethical conduct paved the way to bliss but he added that it also paved the way to prosperity, that is, it was the 'deep determinant' of prosperity. He believed in the power of persuasion and moral and material incentives but never in coercion. According to him, the king was a role model to his employees and public. If he were ethical all elements would also behave in the same manner. Ethical decision-makers would place public interest ahead of their own interests in formulating laws and policies and

${ }^{3}$ Let me provide a small sample of very odd assertions made by Roger Boesche (2002):

(i) He (p 34) writes, "But then, again, Alexander the Great, who must have been one of Kautilya's models, was happy to conquer and assimilate those whom earlier Greeks regarded as strangers or barbarians (barbarous)."

Arthashastra literature started in India somewhere between 600 - 650 BCE. India was way ahead of Greeks so there was not much to learn from them. Well Alexander could not be a role model for anyone. He was a murderer of his good friends and most likely he lost the battle to an Indian king and returned back.

(ii) He (p 32) writes, "As with Hobbes, the goal of science was power. "Power is (possession of) strength and "strength changes the mind," which means that Kautilya' wish would be for power to control not only outward behavior, but also the thoughts of one's subjects and enemies."

He not even come close to what Kautilya was concerned about. Kautilya was worried about a very important concept in economics known as: Time Inconsistency or Credibility Problem that a partner or an ally might not keep his promises. This concept re-emerged after more than two thousand years later and Presscott and Kyland received Nobel Prize for rediscovering it.

(iii) $\mathrm{He}$ ( $\mathrm{p}$ 62) remarks, "If detailed record-keeping is a sign of new despotism, as some such as Weber and Foucault have claimed, then indeed Kautilya's kingdom was despotic."

Kautilya originated the concept of taking Census. He was the founder of statistical economics ([12] Sihag (2013). United States and European Countries undertake census. Are these countries despotic?

(iv) He (pp 61-62) writes, "The king "should conceal, as a tortoise does his limbs, any (limb) of his own that may have become exposed."”

He shows his ignorance of the concept of asymmetric information. Kautilya strongly believed that the possession of private information provided advantages over in bargaining and in preparation against potential adversaries. Akerlof won the Nobel Prize for rediscovering this concept.

(v) He (p 59) writes, "Demanding that subjects work hard in their specialized functions of the division of labor also leaves no time for public life. "For, men being of a nature similar to that of horses, "wrote Kautilya, "change when employed in works... They should carry out the works according to orders, without concerting together."

He misses the point and misinterprets this statement. Shirking, stealing is a serious problem all over the world. In USA employees steal more than the customers, they write emails, talk on the phones and do other things unrelated to their jobs. Nobel laureate Joseph Stiglitz and others recommend paying efficiency wages (higher than the market wages), and supervision to reduce this moral hazard (shirking: not doing what they are supposed to do). Kautilya noticed this problem and suggested efficiency wages, supervision along with moral persuasion to check it. It had nothing to do with the private lives of individuals at their homes. 
in their effective implementation. He argued good institutions would lower risk and good governance would raise the rate return on private investment and that would encourage increases in the supplies of labor, capital and land under cultivation. That would, in turn, lead to a higher economic growth (see Sihag (2014a, Chap. 8) for an in depth analysis). Kautilya devoted more than a third of his book to economic policies and economic administration.

Machiavelli has just one paragraph that may be somewhat relevant to economic wellbeing. He (p 70) wrote, "A ruler also should show himself to be an admirer of skill [virtu] and should honor those who are excellent in any type of work. He should encourage his citizens by making it possible for them to pursue their occupations peacefully, whether they are businessmen, farmers, or engaged in any other activity, making sure they do not hesitate to improve what they own for fear it may be confiscated from them, and they are not discouraged from investing in business for fear of losing their profits in taxes; instead, he should ensure that those who improve and invest are rewarded, as should be anyone whose actions will benefit his city or his government."

Machiavelli did not offer any growth theory. However, he deserves credit for understanding the role of institutions and, to some extent, the role of incentives. Interestingly, Adam Smith understood the importance of institutions but not of incentives, that is, he did not add a whole lot to Machiavelli's insights.

\section{Machiavelli and Kautilya on Administration of Justice}

Kautilya's Arthashastra contains detailed discussion on administration of justice, contract laws, property rules and tort laws (see Sihag (2014a, Chapters 15, 16 1nd 17)). Kautilya believed that only an ethical king, a rajarishi, could enact laws that would promote both efficiency and ethical conduct. Secondly, Kautilya's goal was to develop the cardinal principles of justice, such as punishment should be certain, in proportion to the crime and imposed impartially. Thirdly, too severe or too lenient punishment would erode public's confidence in law implying to impose a reasonable (an internal optimum) level of punishment. Finally and most importantly, the statement 'In the presence of a king maintaining just law, the weak can resist the powerful' connects justice to personal security. Particularly, the phrase 'the weak can resist the powerful' indicates protection of the liberty of the weaker segments of the society. Unlike Mill's negative liberty, the emphasis is on the positive liberty and empowerment of the weak. What Kautilya conveys in one sentence, Mill could not convey in his whole book on liberty ${ }^{4}$ (Table 6).

Machiavelli's goal was to create fear in the minds of public and not administration of justice and most likely would have been ineffective in maintaining law

${ }^{4}$ [13] Huei Chun Su (2009) writes, "In other words, emphasizing the notion of negative liberty is to interpret Mill's principle more from the position of stronger members in a community. If we think about the liberty of the weaker members in the same community, Mill's principle is actually a protection of their positive liberties. In short, Mill's principle of liberty can be interpreted from the other angle: the purpose of limiting some people's liberty is to protect everyone's liberty of life and body." Su is quite liberal in interpreting Mill's negative liberty as positive liberty. 
Table 6. Differences related to Crime and Punishment.

\section{Kautilya}

Kautilya (p 108) elaborated on this theme, "Some teachers say: 'Those who seek to maintain order shall always hold ready the threat of punishment. For, there is no better instrument of control than coercion.' Kautilya disagrees [for the following reasons]. A severe king [meting out unjust punishment] is hated by the people he terrorizes while one who is too lenient is held in contempt by his own people. Whoever imposes just and deserved punishment is respected and honored. A well-considered and just punishment makes the people devoted to dharma, artha and kama [righteousness, wealth and enjoyment]. Unjust punishment, whether awarded in greed, anger or ignorance, excites the fury of even [those who have renounced all worldly attachments like] forest recluses and ascetics, not to speak of householders. When, no punishment is awarded through misplaced leniency and no law prevails, then there is only the law of fish [i.e., the law of the jungle]. Unprotected, the small fish will be swallowed up by the big fish. In the presence of a king maintaining just law, the weak can resist the powerful (1.4)."

Kautilya (p 377) wrote, "A king who observes his duty of protecting his people justly and according to law will go to heaven, whereas one who does not protect them or inflicts unjust punishment will not. It is the power of punishment alone, when exercised impartially in proportion to the guilt, and irrespective of whether the person punished is the King's son or an enemy, that protects this world and the next. (3.1)."
Machiavelli

Pages 9-10: “There is a general rule to be noted here: People should either be caressed or crushed. If you do them minor damage they will get their revenge; but if you cripple them there is nothing they can do. If you need to injure someone, do it in such a way that you do not have to fear their vengeance."

So a ruler ought not to mind the disgrace of being called cruel, if he keeps his subjects peaceful and law-abiding, for it is more compassionate to impose harsh punishments on a few than out of excessive compassion, to allow disorder to spread, which leads to murders or looting. The whole community suffers if there are riots, while to maintain order the ruler only has to execute one or two individuals."

Chapter 12, page 38: "I said above it was necessary for a ruler to lay good foundations; otherwise, he is likely to be destroyed. The principal foundations on which the power of all governments is based (whether they may be new, long-established, or mixed) are good laws and good armies. And, since there cannot be good laws where there are not good armies, and since where there are good armies, there must be good laws, I will omit any discussion of laws, and will talk about armies."

and order. Machiavelli's logic that "since there cannot be good laws where there are not good armies, and since where there are good armies, there must be good laws" is very peculiar.

Laws against Sexual Harassment. Kautilya recommended, "[The Chief Commissioner shall not misbehave with women with whom he has to deal officially]. For looking at the face of a woman or talking about anything other than work, he shall be punished with the lowest level of fine." Women were getting paid for doing the work and the officer was not doing any favor to them.

Laws against Child Labor. He added, "A minor, below eight years of age and no relatives, shall not be made to work, against his will, in menial jobs or in a foreign country." Some of his ideas such as, enacting laws against child labor and sexual harassment truly belong to the later part of $20^{\text {th }}$ century.

Machiavelli remarks, "I conclude, then, that since fortune changes, and men stubbornly continue to behave in the same way, men flourish when their behavior suites the times and fail when they are out of step. I do think, however, that it is better to be headstrong than cautious, for fortune is a lady. It is necessary, if you want to master her, to beat and strike her. And one sees she more often submits to those who act boldly than those who proceed in a calculating fashion. Moreover, since she is a lady, she smiles on the young, for they are less cautious, more ruthless, and overcome her with their boldness."

It is a very offensive analogy, yet, David Wootton offers an apology for Machiavelli. He writes, "Machiavelli, however, unlike these aphorisms, is offensive, and deliberately so: Modern readers notice only the violence between man and woman in chapter twenty-five of The Prince, but sixteenth-century readers 
would have been acutely conscious that fortune is a lady and would have been particularly shocked at the violence between social inferior and superior. It would be wrong, I think, to jump too quickly from Machiavelli's gendered language to a simple reading of Machiavelli as a patriarchal chauvinist."

\section{Kautilya and Machiavelli on National Security}

Kautilya argued that national sovereignty was essential to prosperity since a foreign ruler would be interested only in enriching himself. Then, he reasoned that prosperity was essential to guarding sovereignty since a poor nation would not have adequate resources to provide for strong national security. He understood that if a country focused either only on prosperity or only on national security, could lose both, that is, he understood the inter-dependence of prosperity and security. Also, according to Kautilya, in addition to providing resources, prosperity would win public support [5]. Machiavelli did not understand such interdependence and therefore, paid no attention to bringing prosperity.

Kautilya offered a very comprehensive approach to national security [7]. He realized that national security was not an abstract concept. So the very first step was to set up an intelligence agency to identify friends, foes and neutral rulers, whether they were upright, greedy or wicked and their respective strengths and weaknesses. According to Kautilya, a king's goal should be to reach parity with the potential adversary. Then he proceeded to identify all the factors that were relevant to national security and gave concrete suggestions to achieve their optimum levels. He believed in launching a project/treaty/policy only after undertaking a sound cost-benefit analysis. He would ask three questions. (i) Who should decide the desirability and feasibility of a project/treaty? (ii) What should be their qualifications for making a sound decision? (iii) What type of incentives would be required to elicit optimum effort from them?

Machiavelli was supposedly involved with national security for fourteen years but still did not develop any comprehensive approach to it. He made just a few remarks and only those are compared with those of Kautilya.

Forming Alliances: Kautilya provides an in-depth analysis on why to form alliances, with who, equal, weaker or stronger, upright or otherwise, and how to extract maximum benefits but never to compromise with national security. As an illustration, he suggested, "As between joining forces with a ruler who is stronger than the king or with two rulers of strength equal to the king, it is better to join two equal kings. For with one ruler, the stronger ruler will have the upper hand during the campaign, whereas with two equals the king can keep control. If one of them turns treacherous, it will be easy for the other two to suppress him and make him suffer the consequences of the dissent." On the other hand, Machiavelli offered nothing useful. The following Table 7 presents their respective views on forming alliances.

Apparently, Machiavelli is inconsistent regarding his views on human nature. He (P 52) wrote, "For of men one can, in general, say this: They are ungrateful, fickle, deceptive and deceiving, avoiders of danger, eager to gain." Then a few 
Table 7. Respective advice on forming alliances.

\begin{tabular}{|c|c|}
\hline Kautilya & Machiavelli \\
\hline $\begin{array}{l}\text { (p 573): "Amity with a more powerful monarch carries great danger for } \\
\text { kings, except when one is actually at war with an enemy (7.2)." } \\
\text { (p 624): "The king may face dangers even from a trusted king of equal } \\
\text { power, when the latter has achieved his objective. Even an equally } \\
\text { powerful king tends to become stronger after the task is accomplished } \\
\text { and, when his power has increased, becomes untrustworthy. Prosperity } \\
\text { changes peoples' minds (7.5)." } \\
\text { Proactive Measures: (p 609): "An ally who is likely to grow in power } \\
\text { after defeating the enemy and thus become uncontrollable shall be } \\
\text { embroiled in a conflict with his own neighbor and his own ally; or, a } \\
\text { pretender in his family or an unjustly treated prince shall be } \\
\text { encouraged to seize the throne; or such actions shall be taken as would } \\
\text { oblige the ally to remain obedient, in return for help received (7.18)." }\end{array}$ & $\begin{array}{l}\text { Page 14: "He who is the cause of someone else's becoming powerful } \\
\text { is the agent of his own destruction; for he makes his protége } \\
\text { powerful either through his own skill or through his own strength, } \\
\text { and either of these must provoke his protégé's mistrust once he has } \\
\text { become powerful." } \\
\text { (Chap. 21, P 69: "But when a ruler boldly takes sides, if your ally } \\
\text { wins, even if he is powerful, and has the ability to overpower you, he } \\
\text { is in your debt and fond of you. Nobody is so shameless as to turn } \\
\text { on you in so ungrateful a fashion." } \\
\text { (p 69): "Here it is worth noting a ruler should never take the side } \\
\text { of someone who is more powerful than himself against other rulers, } \\
\text { unless necessity compels him to, as I have already implied." }\end{array}$ \\
\hline
\end{tabular}

pages down, he wrote, "Nobody is so shameless as to turn on you in so ungrateful a fashion." Also he does not propose any precautionary measures to protect the king in case an ally turned against the king.

Role of Information: Kautilya suggested three benefits of having informational advantage. (i) That helped the king in negotiating a more favorable treaty. He stated, "He who, gives a treacherous minister or a treacherous son or daughter as a hostage outmaneuvers the other [the receiver]. The receiver is outmaneuvered because the giver will strike without compunction at the weak point- i.e., the trust that the receiver has that the giver will let the hostage come to harm."

Secondly, it provided an advantage if hostility broke-out with another ruler. He suggested to establish a permanent wing for collection and analysis of latest information. His advice to a king was: "No enemy shall know his secrets. $\mathrm{He}$ shall, however, know all his enemy's weaknesses. Like a tortoise, he shall draw in any limb of his that is exposed." He recommended, "A king shall have his own set of spies, all quick in their work, in the courts of the enemy, the ally, the Middle, and the Neutral kings to spy on the kings as well as their eighteen types of high officials." He added, "He shall always station envoys and clandestine agents in all states of the circle. These shall cultivate those acting against the interests of the conqueror and, while maintaining their own secrecy, destroy repeatedly such inimical persons."

Finally if the king wanted to get rid of land of poor quality. Kautilya stated, "If a settlement of a tract is likely to entail heavy losses or expenditure, a king shall first sell the land, with the intention of reacquiring it, to one who will fail in the attempt at settlement. Such agreements shall remain verbal."

On the other hand, Machiavelli had specified a very limited role for information and there was no intelligence gathering unit to update information. He wrote, "So, since we know the weakness of each of these infantries, we ought to be able to train a new force that will be able to withstand cavalry and will not be afraid of infantry. To accomplish this we need specially designed weapons and new battle formations. This is the sort of new undertaking that establishes the 
reputation and importance of a new ruler."

Public Support. Kautilya believed that public support to a ruler was essential but was conditional on removal of poverty and administration of justice. As mentioned above, Kautilya dealt with both of these topics at length. (i) Removal of poverty. Kautilya explained, "When a people are impoverished, they become greedy; when they are greedy, they become disaffected; when disaffected, they either go to the enemy or kill their ruler themselves." (b) Administration of Justice: Kautilya observed, "When a strong but unjust king is attacked, his subjects will not come to his help but will either topple him or go over to the attacker. On the other hand, when a weak but just king is attacked, his subjects will not only come to his help but also follow him until death."

Machiavelli acknowledges the importance of public support but does not explain why and how to get it. He wrote, "Even if you have an overwhelmingly powerful army, you will have needed the support of the locals to take control of the province."

Type of Army: Kautilya lists several types of army, such as regular standing army, territorial army, organized militias, friendly troops, alien forces and jungle tribe forces. He examines the desirable attributes, such training, loyalty and congruence of objectives of each type. For example, he described, "Regular standing army-composed of natives of the country, dependent on the king, sharing his interests, constantly trained [owing loyalty hereditarily to the royal family, honored by the king]." Kautilya concluded that the regular standing army was the best. He wrote, "It is better to mobilize a force earlier in the list than one later. Because the standing army depends on the king for its existence and because it is constantly under training." He remarked, "Alien troops and jungle tribal forces both have plunder as their objective. [They are both equally untrustworthy]. When there is no plunder or when there is a calamity, they are as dangerous as a viper in one's bosom."

Machiavelli remarked, "A wise ruler, therefore, will always avoid using mercenary and auxiliary troops, and will rely on his own forces. He would rather lose with his own troops than win with someone else's, for he will not regard it a true victory if it is won with troops that do not belong to him." He concluded, "I conclude, therefore, that no ruler is secure unless he has own troops."

We may conclude that Kautilya understood the interdependence of national security and prosperity on each other and developed conceptual frameworks and practical measures to enhance both. On the other hand, Machiavelli had very little to say on enhancing either prosperity or national security.

\section{Conclusions}

It is shown that Kautilya's approach was people-centric whereas Machiavelli's approach was king-centric. Kautilya's objective was to promote Yogakshemapeaceful enjoyment of prosperity — for all the citizens whereas Machiavelli did not entertain such lofty ideals. It is claimed that Kautilya's Arthashastra shifted the knowledge frontier outward whereas Machiavelli's Prince did not even come 
close to incorporating the existing knowledge. Machiavelli's Prince is no match to the depth and breadth of Kautilya's Arthashastra.

Kautilya's Arthashastra is a comprehensive and coherent treatise that contains three inter-linked parts: a) Arthaniti: principles and policies related to economic growth, taxation, international trade, efficient, clean and caring governance, moral and material incentives to elicit effort and preventive and remedial measures to deal with famines, floods and fire; b) Dandaniti: administration of justice, minimization of legal errors, formulation of ethical and efficient laws, labour theory of property, regulation of monopolies and monopsonies, protection of privacy, laws against sexual harassment and child labour and c) Videshniti: all aspects of national security, such as i) energetic, enthusiastic, trained and wellequipped soldiers, most qualified and loyal advisers, strong public support, setting-up an intelligence and analysis wing, ii) negotiating a favourable treaty, iii) military strategy and tactics and diet of soldiers to enhance their endurance.

Machiavelli's suggestions essentially amounted to how a king could change his status from a roving bandit to a stationary bandit. According to him, one should appear to be ethical but need not be ethical and he advanced the maxim: end justifies the means. There is not a single constructive or original suggestion in Machiavelli's Prince. Clearly, negative views expressed on Kautilya's Arthashastra by Roger Boesche, Henry Kissinger, Max Weber and many others have been unsubstantiated. It is shown that comparing Machiavelli's Prince to Kautilya's Arthashastra is like comparing a candle light to that of Sun light. Kautilya was an action-oriented visionary. In sum, a strong case is made to end for good such grossly inappropriate comparisons of these works.

Sihag [8] observes, "Most likely Machiavelli had access to Kautilya's Arthashastra. Since he discusses, although without much depth, many of the same topics, such as forming alliances, role of an adviser, role of information, types of army and specifically the delegation of unpopular task (as discussed below), as were discussed by Kautilya." The current study highlighted the similarities but did not pursue the transmission of ideas. It would be a tremendous addition to the world pool of knowledge if future research could explore specific channels of transmission of ideas among countries.

\section{References}

[1] Machiavelli, N. (1994) Selected Political Writings. Edited and Translated by David Wootton, Hackett Publishing, Cambridge.

[2] Vishnugupta, K. (1992) The Arthashastra. Edited, Rearranged, Translated and Introduced by Rangarajan, L.N., Penguin Books, New Delhi.

[3] Kangle, R.P. (1965/2000) The Kautilya Arthashastra, Part III. Motilal Banarsidass, Delhi.

[4] Kissinger, H. (2014) World Order. Penguin, New York.

[5] Sihag, B.S. (2014) Kautilya: The True Founder of Economics. Vitasta Publications, New Delhi.

[6] Drekmeier, C. (1962) Kingship and Community in Early India. Stanford University Press, Stanford. 
[7] Sihag, B.S. (2014) Kautilya on Far-Sight, Foresight and Freedom. The International Seminar on Kautilya, New Delhi, 9 April 2014.

[8] Sihag, B.S. (2016) Kautilya's Arthashastra: A Recognizable Source of the Wealth of Nations Theoretical Economics Letters, February 2016.

[9] Adam, S. (1776/1976) An Inquiry into the Nature and Causes of the Wealth of Nations. The University of Chicago Press, Chicago.

[10] Boesche, R. (2002) The First Great Political Realist: Kautilya and His Arthashastra. Lexington Books, New York.

[11] Barr, N. (1992) Economic Theory and the Welfare State: A Survey and Interpretation. Journal of Economic Literature, 30, 741-803.

[12] Sihag, B.S. (2013) Kautilya's Arthashastra: The Origin of Statistical Economics during-4CE. Journal of Rajasthan Statistical Association, 2, 1-14.

[13] Su, H.C. (2009) Is Social Justice for or against Liberty? The Philosophical Foundations of Mill and Hayek's Theory of Liberty. The Review of Austrian Economics, 22, 387-414. https://doi.org/10.1007/s11138-008-0057-1

\section{Scientific Research Publishing}

Submit or recommend next manuscript to SCIRP and we will provide best service for you:

Accepting pre-submission inquiries through Email, Facebook, LinkedIn, Twitter, etc. A wide selection of journals (inclusive of 9 subjects, more than 200 journals)

Providing 24-hour high-quality service

User-friendly online submission system

Fair and swift peer-review system

Efficient typesetting and proofreading procedure

Display of the result of downloads and visits, as well as the number of cited articles

Maximum dissemination of your research work

Submit your manuscript at: http://papersubmission.scirp.org/

Or contact tel@scirp.org 